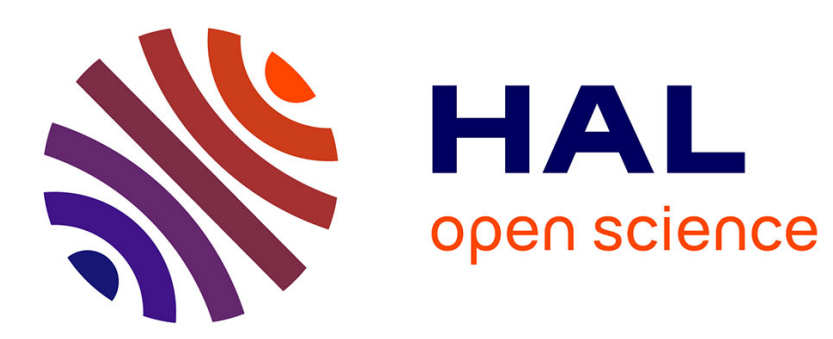

\title{
An expedient route to new spiroheterocycles: synthesis and structural studies.
}

Marlène Goubert, Isabelle Canet, Marie-Eve Sinibaldi

\section{To cite this version:}

Marlène Goubert, Isabelle Canet, Marie-Eve Sinibaldi. An expedient route to new spiroheterocycles: synthesis and structural studies.. European Journal of Organic Chemistry, 2006, pp.4805-4812. 10.1002/ejoc.200600448 . hal-00119575

\section{HAL Id: hal-00119575 \\ https://hal.science/hal-00119575}

Submitted on 27 Feb 2007

HAL is a multi-disciplinary open access archive for the deposit and dissemination of scientific research documents, whether they are published or not. The documents may come from teaching and research institutions in France or abroad, or from public or private research centers.
L'archive ouverte pluridisciplinaire HAL, est destinée au dépôt et à la diffusion de documents scientifiques de niveau recherche, publiés ou non, émanant des établissements d'enseignement et de recherche français ou étrangers, des laboratoires publics ou privés. 


\title{
An Expedient Route to New Spiroheterocycles: Synthesis and Structural Studies
}

\author{
Marlène Goubert, ${ }^{|\mathrm{a}|}$ Isabelle Canet, ${ }^{|\mathrm{a}|}$ and Marie-Eve Sinibaldi $*|\mathrm{a}|$
}

Keywords: Spiro compounds / Heterocycles / Nucleophilic substitution / Cyclization

We have developed a short, efficient and enantioselective synthesis of 1,4,7,10-tetraoxa- and 1,7-dioxa-4,10-dithiaspiro[5.5] undecanes. The method involved the reaction of solketal 5 or thiol derivative 6 with 1,3-dichloropropanone O-benzyloxime (4) which affords the conveniently protected symmetrical ketones 7 and 8 . Elaboration of the required 4,10-disubstituted-1,7-dioxaspiro[5.5]undecane systems 1 and 2 entailed a final "one-pot" deprotection-spirocyclization process in an acidic medium. The structures and configurations of the spiroketals were established unambiguously by NMR spectroscopy.

(๑ Wiley-VCH Verlag GmbH \& Co. KGaA, 69451 Weinheim, Germany, 2006)

\section{Introduction}

Significant attention has been focused on the synthesis of the 1,7-dioxaspiro[5.5] undecane moiety which is the prevalent underlying motif in several groups of bioactive natural products, from the simple spiroketals used as pheromones ${ }^{[1]}$ by a large number of insect species, to more complex molecules such as polyether antibiotics ${ }^{[2]}$ and antitumour compounds. ${ }^{[3]}$ This diversity has led to interest in the development of original methods for the preparation of this framework and a number of strategies have been investigated. ${ }^{[4]}$ Moreover, new spiroketal compounds with a supplementary heteroatom at the position $\beta$ to the spiranic carbon atom have been reported that possess interesting biological activities, such as the NK1 antagonists ${ }^{[5]}$ or anthelmintic agents ${ }^{[6]}$ (Figure 1).

We recently described an efficient diastereoselective approach to spiroketals ${ }^{[7]}$ and spiroaminoketals ${ }^{[8]}$ based upon an acidic deprotection-cyclization key step of a linear $\alpha, \omega$ dihydroxy- or an $\alpha$-amino- $\omega$-hydroxy ketone, protected as its dimethylhydrazone, respectively.

As a continuation of our research program devoted to the synthesis and biological evaluation of various spiroketal analogues, we have explored the viability of incorporating heteroatoms into the skeleton of spiroketals. We describe here a new and expedient route towards 4,10-disubstituted1,7-dioxaspiro[5.5]undecanes $\mathbf{1}$ and $\mathbf{2}$ as well as full conformational and structural studies on these spiroketals based on various NMR experiments.

[a] Laboratoire de Synthèse et d'Etude de Systèmes à Intérêt Biologique, UMR CNRS 6504, Université Blaise Pascal,

63177 Aubière Cedex, France

E-mail: isabelle.canet@univ-bpclermont.fr m-eve.sinibaldi-troin@univ-bpclermont.fr<smiles>C[C@H]1CCCO[C@@]12CC[C@@H](C)[C@H](COCc1ccccc1)O2</smiles>

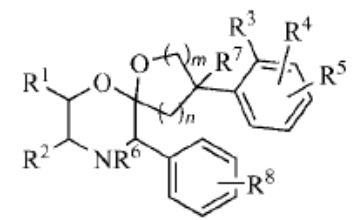

apoptosis-inducing agent antagonists NKl

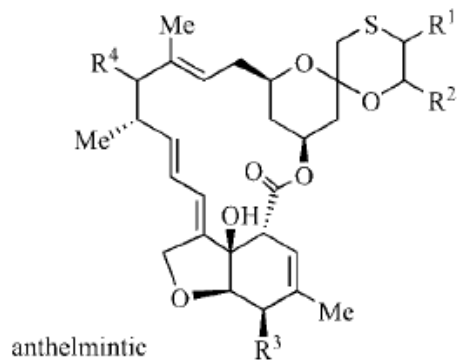

Figure 1. New spiroketal compounds with interesting biological properties.

\section{Results and Discussion}

\section{Chemistry}

We first tried to introduce heteroatoms into the 4- and 10-positions of the spiroketal framework using a strategy similar to the one we reported for simple spiroketals. ${ }^{[7]}$ In this way, we envisioned constructing the target skeleton by substitution of the hydrazone 3 with commercially available solketal 5 or its thiol derivative 6 . In situ acidic deprotection of the bis-alkylated intermediates 7 or 8 would lead to a nonisolated symmetrical keto-tetraol, which should spontaneously undergo spirocyclization into the required spirohet- 
erocyclic compounds 1 or $\mathbf{2}$ (Scheme 1). However, in spite of numerous attempts, we unfortunately never obtained hydrazone 7a. Therefore, we focused on a new approach to scaffold 1 and 2, modifying the nature of the protective group on $\mathbf{3}$, namely by using the benzyloxime $\mathbf{4}$ (Scheme 1).

$$
\begin{array}{ll}
3 \mathrm{R}^{\prime}=\mathrm{N}\left(\mathrm{CH}_{3}\right)_{2} & \substack{\mathbf{5}=\mathrm{O} \\
\mathbf{6 X}=\mathrm{S}} \\
4 \mathrm{R}^{\prime}=\mathrm{OBn} & \rightarrow
\end{array}
$$

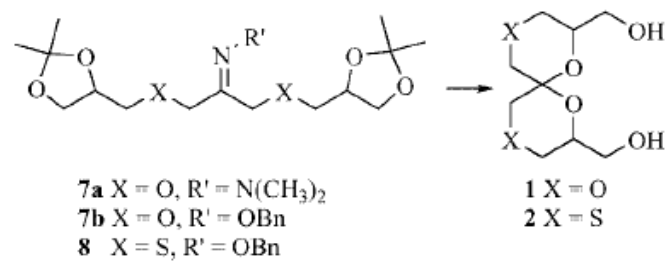

Scheme 1. Preparative routes to 4,10-disubstituted-1,7-dioxaspiro[5.5]undecanes.

The starting point was the synthesis of precursors 4 and 6. Condensation of 1,3-dichloropropanone in EtOH with benzylhydroxylamine hydrochloride ${ }^{[9]}$ led quantitatively to oxime 4. Racemic thiol 6 (Scheme 2) was obtained from commercially available 3-mercapto-1,2-propanediol by simple treatment with acetone using a catalytic amount of PPTS in the presence of $\mathrm{MgSO}_{4}{ }^{[10]}$ and was isolated in $64 \%$ yield. Enantiopure $(R)$ - and $(S)$-6 were obtained from $(S)$ and $(R)$-solketal 5 in 75 and $52 \%$ overall yields, respectively, in three steps. Compounds $(S)$ - or $(R)-5$ were first converted to tosylate 9 using $p$-toluenesulfonyl chloride and a mixture of $\mathrm{NEt}_{3} / \mathrm{DMAP}$ in dry $\mathrm{CH}_{2} \mathrm{Cl}_{2}$. The tosyl ether was then displaced with potassium thioacetate in boiling acetone. [11a] Cleavage of the crude thioacetate 10 with a $5 \mathrm{M}$ aqueous solution of $\mathrm{NaOH}$ in EtOH furnished the expected thiols. ${ }^{[11 b]}$
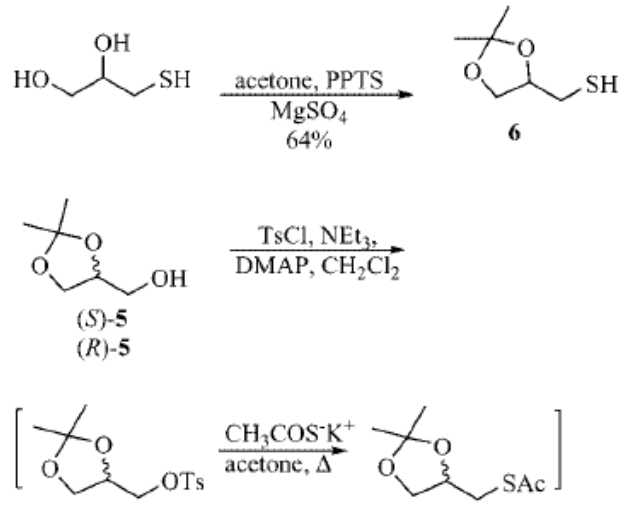

9

10

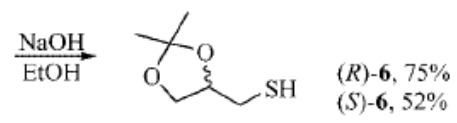

Scheme 2. Preparation of thiols 6 .

Having the precursors in hand, we then studied their condensation reactions with oxime 4 under basic conditions. The double substitution ${ }^{[9]}$ of 4 (Scheme 3 ) by the sodium or the potassium salt of $\mathbf{5}$ in DMF or THF afforded the expected oxime $7 \mathbf{b}$ in good yields (see Table 1). The best results were obtained with $\mathrm{KH}$ in THF. Consequently, these reaction conditions were applied to the condensation of 4 with 6 and led as expected to 8 in $80-90 \%$ yields (Scheme 4).

Table 1. Substitution of oxime $\mathbf{4}$ with solketal 5.

\begin{tabular}{lllll}
\hline Entry & Compound 7b & Solvent & Base & Isolated yield [\%] \\
\hline 1 & $\left(R^{*}, S^{*}\right)$ - and $\left(S^{*}, S^{*}\right)-7 \mathbf{b}$ & $\mathrm{DMF}$ & $\mathrm{NaH}$ & 79 \\
& & THF & $\mathrm{KH}$ & 85 \\
2 & $(S, S)-7 \mathbf{b}$ & $\mathrm{DMF}$ & $\mathrm{NaH}$ & $28^{[\mathbf{a}]}$ \\
& & THF & $\mathrm{KH}$ & 70 \\
3 & $(R, R)-7 \mathbf{b}$ & $\mathrm{DMF}$ & $\mathrm{NaH}$ & 61 \\
& & THF & $\mathrm{KH}$ & 87
\end{tabular}

[a] Sodium alcoholate of $(S)$-solketal led surprisingly to a gelled solution, which showed poor reactivity.

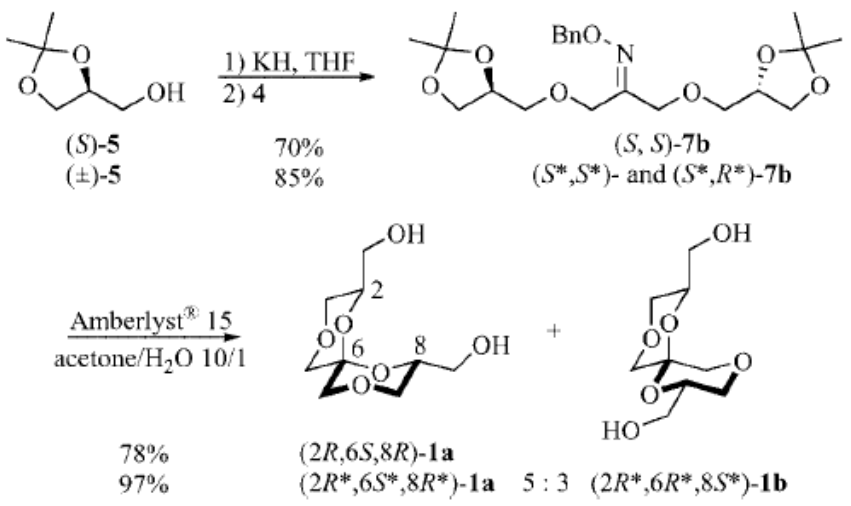

Scheme 3. Synthesis of 1,4,7,10-tetraoxaspiro[5.5]undecane 1. 

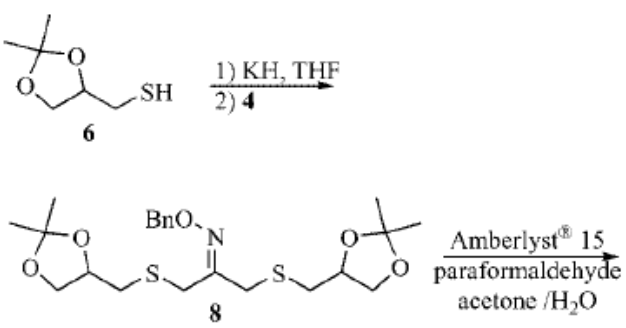
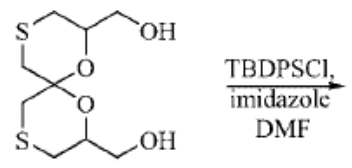

2

2 TBAF, THF

Scheme 4. Synthesis of 1,7-dioxa-4,10-dithiaspiro[5.5]undecanes 2 and 11.

The second step involved concomitant deprotection of the diol and the keto functions of $\mathbf{7 b}$ and $\mathbf{8}$ and spirocyclization into 1 and 2 . For this purpose, we first treated $7 \mathbf{b}$ with Amberlyst ${ }^{\circledR} 15$ in a 10:1 mixture of acetone/water. In this way, spiroketals $(2 R, 6 S, 8 R)$ - and $(2 S, 6 R, 8 S)$-1a were cleanly obtained from $(S)$ - and $(R)-5$ in 55 and $52 \%$ overall yields, respectively (Scheme 3). Spiroketal 1 a presents, as expected, a double anomeric effect and has $C_{2}$ symmetry with both cycles adopting a chair conformation. ${ }^{[12]}$ Compound $( \pm)-5$ led, in an $82 \%$ overall yield, to a mixture of $\left(2 R^{*}, 6 S^{*}, 8 R^{*}\right)$ 1a and $\left(2 R^{*}, 6 R^{*}, 8 S^{*}\right)$-1b ( $5: 3$ ratio determined by quantitative ${ }^{13} \mathrm{C}$ NMR spectroscopy), which were easily separated by purification on silica gel and fully characterized. ${ }^{[12]}$

Applying the same conditions to oxime 8 led unfortunately to the sole deprotection of the diol function. The deprotection-spirocyclization sequence was finally achieved by adding paraformaldehyde to the acidic medium (Scheme 4). ${ }^{[13]}$ Enantiopure $(R, R)-8$ furnished, in a $75 \%$ yield, an inseparable mixture of C-6 epimers $(2 R, 6 S, 8 R)-2 \mathrm{a}$ and $(2 R, 6 R, 8 R)-2 \mathbf{b}$ in a $10: 7$ ratio (Figure 2$)$. Their enantiomers were obtained efficiently starting from enantiopure $(S, S)-8$ (71\% yield). The cyclization step proceeded with a lower stereoselectivity than was the case for the tetraoxa series; the importance of the anomeric effect in the cyclization process was reduced by the presence of the less electron-withdrawing atoms in the molecule.

In order to isolate $\mathbf{2} \mathbf{a}$ and $\mathbf{2 b}$, we prepared their TBDPS derivatives 11a,b (Scheme 4) using TBDPSCl/imidazole in DMF. Flash column chromatography on $\mathrm{SiO}_{2}$ allowed the clean separation of 11a of 11b. Alcohols 2a and 2b were then recovered by classical treatment with TBAF in THF.

Starting from $( \pm)-6$, oximes $\left(R^{*}, R^{*}\right)$ - and $\left(R^{*}, S^{*}\right)-8$ furnished four diastereomers, $\left(2 R^{*}, 6 S^{*}, 8 R^{*}\right)-\mathbf{2}$, $\left[\left(2 R^{*}, 6 R^{*}, 8 R^{*}\right)-2 \mathrm{~b}+{ }^{+} \quad\left(2 R^{*}, 6 S^{*}, 8 S^{*}\right)-2 \mathrm{c}\right] \quad$ and $\left(2 R^{*}, 6 R^{*}, 8 S^{*}\right)-2 \mathrm{~d}$, in a $78 \%$ yield and a $5: 7: 1$ ratio, as determined by quantitative ${ }^{13} \mathrm{C}$ NMR spectroscopy. Isomer 2d could be separated at this stage from the three others. A TBDPS protection-chromatography-deprotection sequence allowed us to obtain $2 \mathbf{a}$ cleanly, but $\mathbf{2 b}$ and $\mathbf{2 c}$ remained

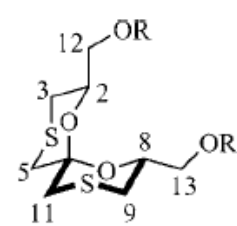

$(2 R, 6 S, 8 R)-11$ a $(2 R, 6 S, 8 R)-\mathbf{2 a}$

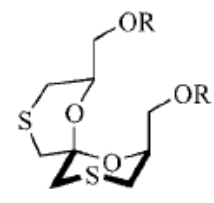

$(2 R, 6 S, 8 S)-11 \mathrm{c}$ $(2 R, 6 S, 8 S)-2 \mathbf{c}$

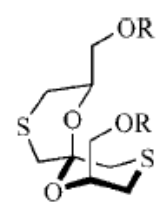

$(2 R, 6 R, 8 R)-\mathbf{1 1 b}$ $(2 R, 6 R, 8 R)-\mathbf{2 b}$
Figure 2. Structures of the isomers of the spiroketals $11(\mathrm{R}=$ TBDPS) and $2(\mathrm{R}=\mathrm{H})$.

inseparable. In order to characterize $\left(2 R^{*}, 6 S^{*}, 8 S^{*}\right)-2 \mathrm{c}$, we therefore conducted the reaction on $(R, S)-8$. We isolated the two C-6 epimers $(2 R, 6 S, 8 S)-\mathbf{2}$ and $(2 R, 6 R, 8 S)-2 \mathbf{d}$ in $44 \%$ yield, with $2 \mathrm{~d}$, as before, the minor compound (Figure 2).

\section{Structural and Conformational Studies of Spiroketals 2}

Analysis of the ${ }^{1} \mathrm{H}$ and ${ }^{13} \mathrm{C}$ NMR spectra of isomers $(2 R, 6 S, 8 R)-\mathbf{2 a}, \quad(2 R, 6 R, 8 R)-\mathbf{2 b}, \quad(2 R, 6 S, 8 S)-2 \mathbf{c} \quad$ and $(2 R, 6 R, 8 S)-2 d$ with the help of COSY, HETCOR and in particular NOESY experiments permitted us to assign all the ${ }^{1} \mathrm{H}$ and ${ }^{13} \mathrm{C}$ resonances (Figure 2, Table 2).

Compound 2a presented a simplified ${ }^{1} \mathrm{H}$ NMR spectrum and only five peaks were detected in its ${ }^{13} \mathrm{C}$ NMR spectrum, which is in good agreement with a $C_{2}$ symmetrical structure. As the deprotection-spirocyclization sequence was conducted under thermodynamic control, we concluded that the configuration was unambiguously $(2 R, 6 S, 8 R)$. As for 1a, $2-\mathrm{H}$ and $8-\mathrm{H}$ are in an axial position on the cycles adopting a chair conformation, as illustrated by the large coupling constants $(11.5 \mathrm{~Hz})$ measured between $2-\mathrm{H}$ and $3-\mathrm{H}^{\mathrm{ax}}, 8-\mathrm{H}$ and $9-\mathrm{H}^{\mathrm{ax}}$, and the small ones (not measurable in the ${ }^{1} \mathrm{H}$ NMR spectrum, crosspeak on COSY) between $2-\mathrm{H} / 3-\mathrm{H}^{\mathrm{eq}}$ and $8-\mathrm{H} / 9-\mathrm{H}^{\mathrm{eq}}$, respectively.

As compound $\mathbf{2 b}$ is the $\mathrm{C}-6$ epimer of $\mathbf{2} \mathbf{a}$, we assumed its configuration was $(2 R, 6 R, 8 R)$. The small coupling constants (less than $2.0 \mathrm{~Hz}$, not measurable in the ${ }^{1} \mathrm{H}$ NMR spectrum) for $8-\mathrm{H}$ (br. d, $\delta=4.77 \mathrm{ppm}$ ) with both $9-\mathrm{H}$ atoms $(\mathrm{d}, \delta=2.19 \mathrm{pm}$ and $\delta=3.11 \mathrm{pm})$ and the distances between $8-\mathrm{H}$ and $9-\mathrm{H}$ (obtained from NOESY of $11 \mathrm{~b}$, see Figure 3) indicated an equatorial position of $8-\mathrm{H}$ on the cycle that adopted a chair conformation. The coupling constants of 7.0 and $5.0 \mathrm{~Hz}$ observed between $2-\mathrm{H}(\mathrm{dq}, \delta=$ $3.71 \mathrm{ppm})$ and $3-\mathrm{H}^{\mathrm{a}}(\delta=2.77 \mathrm{ppm})$ and $3-\mathrm{H}^{\mathrm{b}}(\delta=$ $2.64 \mathrm{ppm}$ ) led to the assignment of a "boat" deformation for the upper cycle, and thus a pseudoaxial position for 2- 
Table 2. ${ }^{1} \mathrm{H}$ and ${ }^{13} \mathrm{C}$ NMR spectroscopic data of isomers of $\mathbf{2}$.

\begin{tabular}{|c|c|c|c|c|c|c|c|c|}
\hline & \multicolumn{2}{|c|}{$(2 R, 6 S, 8 R)-\mathbf{2} \mathbf{a}$} & \multicolumn{2}{|c|}{$(2 R, 6 R, 8 R)-\mathbf{2 b}$} & \multicolumn{2}{|c|}{$(2 R, 6 S, 8 S)-\mathbf{2} \mathbf{c}$} & \multicolumn{2}{|r|}{$(2 R, 6 R, 8 S)-\mathbf{2 d}$} \\
\hline & $\delta_{\mathrm{c}}$ & $\delta_{\mathrm{H}}$ & $\delta_{\mathrm{e}}$ & $\delta_{\mathrm{H}}$ & $\delta_{\mathrm{c}}$ & $\delta_{\mathrm{H}}$ & $\delta_{\mathrm{c}}$ & $\delta_{\mathrm{H}}$ \\
\hline 2 & 72.4 & $\begin{array}{l}3.97(\mathrm{dt}) \\
(J 11.5 ; 5.0)\end{array}$ & 72.9 & $\begin{array}{l}3.71(\mathrm{dq}) \\
(J 7.0 ; 5.0)\end{array}$ & 72.9 & $\begin{array}{l}3.69(\mathrm{dq}) \\
(J 7.0 ; 5.0)\end{array}$ & 72.1 & $\begin{array}{l}3.81 \text { (dddd) } \\
(J 10.5 ; 6.0 ; 5.0 ; 2.0)\end{array}$ \\
\hline 3 & 27.8 & $\begin{array}{l}2.37(\mathrm{~d}) \\
(J 11.5) \\
2.54(\mathrm{t}) \\
(J 11.5)\end{array}$ & 37.8 & $\begin{array}{l}2.64(\mathrm{ddd}) \\
(J 13.5 ; 7.0 ; 2.0) \\
2.77(\mathrm{dd}) \\
(J 13.5 ; 5.5)\end{array}$ & 37.8 & $\begin{array}{l}2.63(\mathrm{dd}) \\
(J 13.5 ; 7.0) \\
2.75(\mathrm{dd}) \\
(J 13.5 ; 5.0)\end{array}$ & 29.7 & $\begin{array}{l}2.42 \text { (br. d) } \\
(J 13.5) \\
2.54 \text { (dd) } \\
(J 13.5 ; 10.5)\end{array}$ \\
\hline 5 & 35.2 & $\begin{array}{l}2.40(\mathrm{~d}) \\
(J 13.5) \\
2.76(\mathrm{~d}) \\
(J 13.5)\end{array}$ & 40.6 & $\begin{array}{l}2.83(\mathrm{~d}) \\
(J 14.0) \\
2.84(\mathrm{~d}) \\
(J 14.0)\end{array}$ & 40.6 & $\begin{array}{l}2.80(\mathrm{~d}) \\
(J 15.0) \\
2.83(\mathrm{~d}) \\
(J 15.0)\end{array}$ & 28.7 & $\begin{array}{l}2.42(\mathrm{~d}) \\
(J 13.5) \\
2.69(\mathrm{~d}) \\
(J 13.5)\end{array}$ \\
\hline 6 & 91.9 & & 108.3 & & 108.3 & & 94.7 & \\
\hline 8 & 72.4 & $\begin{array}{l}3.97(\mathrm{dt}) \\
(J 11.5 ; 5.0)\end{array}$ & 76.3 & $\begin{array}{l}4.77 \text { (br. d) } \\
(J 6.0)\end{array}$ & 76.3 & $\begin{array}{l}4.75 \text { (br. d) } \\
(J 6.0)\end{array}$ & 76.3 & $\begin{array}{l}4.36(\mathrm{dtd}) \\
(J 11.0 ; 5.0 ; 2.0)\end{array}$ \\
\hline 9 & 27.8 & $\begin{array}{l}2.37(\mathrm{~d}) \\
(J 11.5) \\
2.54(\mathrm{t}) \\
(J 11.5)\end{array}$ & 29.7 & $\begin{array}{l}2.19(\mathrm{~d}) \\
(J 13.0) \\
3.11(\mathrm{~d}) \\
(J 13.0)\end{array}$ & 29.7 & $\begin{array}{l}2.18 \text { (br. d) } \\
(J 13.0) \\
3.09 \text { (br. d) } \\
(J 13.0)\end{array}$ & 28.3 & $\begin{array}{l}2.37(\mathrm{dt}) \\
(J 13.0 ; 2.0) \\
2.55(\mathrm{dd}) \\
(J 13.0 ; 11.0)\end{array}$ \\
\hline 11 & 35.2 & $\begin{array}{l}2.40(\mathrm{~d}) \\
(J 13.5) \\
2.76(\mathrm{~d}) \\
(J 13.5)\end{array}$ & 33.9 & $\begin{array}{l}2.44(\mathrm{~d}) \\
(J 13.0) \\
3.01(\mathrm{~d}) \\
(J 13.0)\end{array}$ & 33.9 & $\begin{array}{l}2.42(\mathrm{~d}) \\
(J 13.0) \\
2.99(\mathrm{~d}) \\
(J 13.0)\end{array}$ & 35.9 & $\begin{array}{l}2.64(\mathrm{~d}) \\
(J 14.5) \\
3.58(\mathrm{dd}) \\
(J 14.5 ; 2.0)\end{array}$ \\
\hline 12 & 65.9 & $\begin{array}{l}3.48(\mathrm{dd}) \\
(J 11.5 ; 5.0) \\
3.56(\mathrm{dd}) \\
(J 11.5 ; 5.0)\end{array}$ & 66.0 & $\begin{array}{l}3.49(\mathrm{dd}) \\
(J 11.0 ; 5.5) \\
3.54(\mathrm{dd}) \\
(J 11.0 ; 5.0)\end{array}$ & 66.0 & $\begin{array}{l}3.47(\mathrm{dd}) \\
(J 11.0 ; 5.0) \\
3.52(\mathrm{dd}) \\
(J 11.0 ; 5.5)\end{array}$ & 65.9 & $\begin{array}{l}3.53(\mathrm{dd}) \\
(J 11.0 ; 6.0) \\
3.61(\mathrm{dd}) \\
(J 11.0 ; 5.0) \\
\end{array}$ \\
\hline 13 & 65.9 & $\begin{array}{l}3.48(\mathrm{dd}) \\
(J 11.5 ; 5.0) \\
3.56(\mathrm{dd}) \\
(J 11.5 ; 5.0)\end{array}$ & 70.8 & $\begin{array}{l}3.94(\mathrm{l}) \\
(J 6.0) \\
4.33(\mathrm{~d}) \\
(J 6.5)\end{array}$ & 70.8 & $\begin{array}{l}3.93(\mathrm{t}) \\
(J 6.0) \\
4.31(\mathrm{~d}) \\
(J 6.0)\end{array}$ & 66.0 & $\begin{array}{l}3.41(\mathrm{dd}) \\
(J 11.0 ; 5.0) \\
3.47(\mathrm{dd}) \\
(J 11.0 ; 5.0)\end{array}$ \\
\hline
\end{tabular}

$H$. This conformation was also confirmed by the NOE contacts determined for $11 \mathrm{~b}$ between $2-\mathrm{H}(\delta=3.71 \mathrm{ppm})$ and $3-\mathrm{H}^{\mathrm{b}}(\delta=2.64 \mathrm{ppm}), 2-\mathrm{H}$ and $5-\mathrm{H}^{\mathrm{a}}(\delta=2.83 \mathrm{ppm})$, and 5$\mathrm{H}^{\mathrm{a}}(\delta=2.83 \mathrm{ppm})$ and $3-\mathrm{H}^{\mathrm{b}}(\delta=2.64 \mathrm{ppm})$ (Figure 3$)$. The deshielding of $5-\mathrm{H}(\delta=2.83$ and $2.84 \mathrm{ppm}$ in $2 \mathbf{b}$ and $\delta=$ 2.40 and $2.76 \mathrm{ppm}$ in 2a) and of C-5 ( $\delta=40.6 \mathrm{ppm}$ in $\mathbf{2 b}$ and $\delta=35.2 \mathrm{ppm}$ in 2a) favour an (R) configuration for C6. Moreover, the deshielding of $\mathrm{C}-13$ ( $\delta=70.8 \mathrm{ppm}$ in $\mathbf{2 b}$ and $\delta=65.9 \mathrm{ppm}$ in 2a) and $13-\mathrm{H}(\delta=4.33$ and $3.94 \mathrm{ppm}$ in $2 \mathbf{b}$ vs. $\delta=3.56$ and $3.48 \mathrm{ppm}$ in 2a) implied a 1,3-diaxial position for $\mathrm{C}-13$ and $\mathrm{O}-1$, which is in agreement with the conformation depicted in Figure 2 for $\mathbf{2} \mathbf{b}$.
The determination of the C- 6 configuration for the other isomers $\mathbf{2} \mathbf{c}$ and $\mathbf{2 d}$ did not appear so trivial. In the minor isomer $2 \mathrm{~d}, 2-\mathrm{H}$ and $8-\mathrm{H}$ appeared in an axial position: indeed, we observed for $2-\mathrm{H}(\delta=3.81 \mathrm{ppm})$ a coupling constant of $10.5 \mathrm{~Hz}$ with $3-\mathrm{H}^{\text {ax }}$ and of $2.0 \mathrm{~Hz}$ with $3-\mathrm{H}^{\mathrm{eq}}$. In the same manner, 8- $\mathrm{H}$ presented coupling constants of 11.0 and $2.0 \mathrm{~Hz}$ with $9-\mathrm{H}^{\mathrm{ax}}$ and $9-\mathrm{H}^{\mathrm{eq}}$, respectively. Moreover, we detected in this isomer a deshielding of $11-\mathrm{H}^{\text {eq }}(\delta=$ $3.58 \mathrm{ppm}$ ) and a shielding of C-5 which is in complete agreement with an equatorial position of the C-6-O-7 bond. These results were corroborated by the NOE contacts determined for 11d between $11-\mathrm{H}^{\mathrm{ax}}$ and $5-\mathrm{H}^{\mathrm{ax}}$ and between 


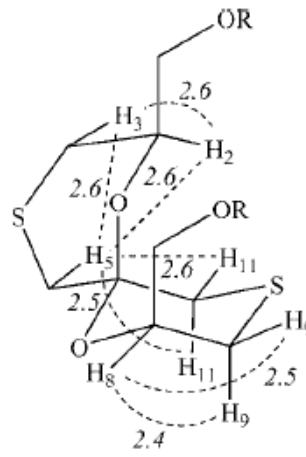

$(2 R, 6 R, 8 R)-11 \mathbf{b}$

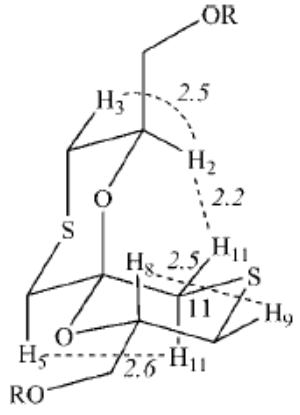

$(2 R, 6 R, 8 S)-11 \mathbf{d}$
Figure 3. Selected NOE interactions in $11 \mathrm{~b}$ and $11 \mathrm{~d}$. The relative distances (in $\AA$ ) calculated from the NOEs are indicated.

$2-\mathrm{H}$ and $11-\mathrm{H}^{\mathrm{eq}}$ (Figure 3). All these data are in good agreement with a $(2 R, 6 R, 8 S)$ configuration for $\mathbf{2 d}$.

Isomer $\mathbf{2 c}$, whose $R_{\mathrm{f}}$ is identical to that of isomer $\mathbf{2 b}$, presented a ${ }^{13} \mathrm{C}$ NMR spectrum identical to that of isomer 2b. In the ${ }^{1} \mathrm{H}$ NMR spectrum only slight differences could be detected: indeed, only three protons exhibited "dedoubled" signals. These spectroscopic data indicate a structure for $\mathbf{2 c}$ similar to that of $\mathbf{2 b}$. As compound $\mathbf{2 c}$ is the C6 epimer of $2 d$, all these observations are in agreement with a "boat" conformation for the O-1 cycle and an $(S)$ configuration for $\mathrm{C}-6$. Therefore we concluded that the configuration of $2 \mathrm{c}$ should be $(2 R, 6 S, 8 S)$.

\section{Conclusions}

In summary, we have developed a concise and original method for the synthesis of new spiroketals with supplementary heteroatoms in the 4- and 10-positions of the cycles. The key step involved the condensation of 1,3-disubstituted-propanone $O$-benzyloxime 4 with alcohol 5 or thiol 6. The versatility and the efficiency of our approach have been demonstrated by the synthesis, in a few steps with good yields, of symmetrical elaborated molecules of the 1,4,7,10-tetraoxa- and 1,7-dioxa-4,10-dithiaspiro[5.5]undecane series from commercially available solketal and 1,3-dichloropropanone.

\section{Experimental Section}

General Remarks: NMR spectra were recorded with a Bruker AC 400 spectrometer operating at $400 \mathrm{MHz} .{ }^{1} \mathrm{H}$ and ${ }^{13} \mathrm{C}$ NMR were recorded in $\mathrm{CDCl}_{3}$ or $\mathrm{CD}_{3} \mathrm{OD}$; chemical shifts are calibrated to the residual proton and carbon resonances of the solvent $\left(\mathrm{CDCl}_{3}: \delta_{\mathrm{H}}\right.$ $\left.=7.26, \delta_{\mathrm{C}}=77.0 \mathrm{ppm} ; \mathrm{CD}_{3} \mathrm{OD}: \delta_{\mathrm{H}}=3.34, \delta_{\mathrm{C}}=49.0 \mathrm{ppm}\right)$. Data are reported as follows: chemical shift, multiplicity $(\mathrm{s}=$ singlet, $\mathrm{d}$ $=$ doublet, $\mathrm{t}=$ triplet, $\mathrm{q}=$ quartet, quint $=$ quintuplet, $\mathrm{m}=$ multiplet, br. $\mathrm{d}=$ broad doublet; when coupling constants ${ }^{2} J$ and ${ }^{3} J$ are identical, the multiplicity "t" is attributed, a doublet when ${ }^{2} J$ is different of ${ }^{3} \mathrm{~J}$, coupling constants $(\mathrm{Hz})$, integration and assignment. Mass spectra were recorded with a Hewlett-Packard 5989B instrument. High-resolution mass spectra were performed with a Q-TOF micromass spectrometer. Optical rotations were measured at the sodium D line $(589 \mathrm{~nm})$ using a $1-\mathrm{dm}$ quartz cell with a JASCO DIP-370 apparatus. Infrared spectra were recorded with a Perkin-Elmer spectrometer. Melting points were determined with a hot-stage Reichert apparatus and are uncorrected. Flash column chromatography was performed using silica gel 60 (Macherey-Nagel, $0.04-0.063 \mathrm{~mm}$ ). Dry tetrahydrofuran was distilled from potassium and benzophenone, whereas dry dichloromethane was distilled from $\mathrm{CaH}_{2}$. Reactions were generally run under argon. All commercially available compounds (Acros, Aldrich) were used as received. TLC analysis was conducted using the spray reagent molybdic acid and by further heating until development of colour. Compound 4 was synthesized according to ref. ${ }^{[9]}$

1,3-Bis|(4S)-(2,2-dimethyl-1,3-dioxolan-4-yl)methoxy|propanone $O$ Benzyloxime (7b): Solketal $(S)-5(630 \mathrm{mg}, 4.76 \mathrm{mmol})$ in THF $(4 \mathrm{~mL})$ was slowly added to a stirred suspension of potassium hydride $(25-35 \%$ in mineral oil, $870 \mathrm{mg}, 6.50 \mathrm{mmol})$ in anhydrous THF $(9 \mathrm{~mL})$ under argon at $20^{\circ} \mathrm{C}$. When bubbling had ceased (ca. $30 \mathrm{~min}), \quad 1,3$-dichloropropanone $O$-benzyloxime $4 \quad(500 \mathrm{mg}$, $2.16 \mathrm{mmol})$ in THF $(3 \mathrm{~mL})$ was added in one portion. The reaction mixture was stirred at room temperature for $2 \mathrm{~h}$. Additional $\mathrm{KH}$ could be added if starting material was left. The reaction was quenched by the addition of $\mathrm{H}_{2} \mathrm{O}(7 \mathrm{~mL})$ followed by $\mathrm{CH}_{2} \mathrm{Cl}_{2}$ $(30 \mathrm{~mL})$. The aqueous phase was extracted with $\mathrm{CH}_{2} \mathrm{Cl}_{2}$ $(2 \times 15 \mathrm{~mL})$ and the combined organic layers were washed with brine $(15 \mathrm{~mL})$ and dried with $\mathrm{MgSO}_{4}$. After filtration, the solvent was removed. The residue was purified by flash column chromatography (cyclohexane/ethyl acetate, $4: 1$ ) to afford $7 \mathbf{b}$ as a colourless oil.

$(S, S)$-7b: Yield 70\% $(640 \mathrm{mg}) . R_{\mathrm{f}}=0.51$ (cyclohexane/EtOAc, 7:3). $[a]_{\mathrm{D}}^{5}=+13.9\left(c=1.2, \mathrm{CHCl}_{3}\right)$. IR (neat): $\tilde{\mathrm{v}}=1680(\mathrm{C}=\mathrm{N}) \mathrm{cm}^{-1}$. ${ }^{1} \mathrm{H}$ NMR (400 MHz, $\left.\mathrm{CDCl}_{3}\right): \delta=7.37-7.28(\mathrm{~m}, 5 \mathrm{H}, \mathrm{Ar}-\mathrm{H}), 5.10$ (s, $2 \mathrm{H}, \mathrm{CH}_{2}-\mathrm{Ar}$ ), 4.40 (d, ${ }^{2} J=14.5 \mathrm{~Hz}, 1 \mathrm{H}, \mathrm{N}=\mathrm{C}-\mathrm{CH}_{2}-\mathrm{O}$ ), 4.38 (d, ${ }^{2} J=14.5 \mathrm{~Hz}, 1 \mathrm{H}, \mathrm{N}=\mathrm{C}-\mathrm{CH}_{2}-\mathrm{O}$ ), 4.24 (quint, ${ }^{3} J=6.0 \mathrm{~Hz}, 2 \mathrm{H}$, $\mathrm{CH}-\mathrm{O}), 4.17\left(\mathrm{~s}, 2 \mathrm{H}, \mathrm{N}=\mathrm{C}-\mathrm{CH}_{2}-\mathrm{O}\right), 4.02\left(\mathrm{t},{ }^{2} J={ }^{3} J=6.5 \mathrm{~Hz}, 2 \mathrm{H}\right.$, $\left.\mathrm{CH}_{2}-\mathrm{O}\right), 3.71\left(\mathrm{t},{ }^{2} J={ }^{3} \mathrm{~J}=6.5 \mathrm{~Hz}, 1 \mathrm{H}, \mathrm{CH}_{2}-\mathrm{O}\right), 3.69\left(\mathrm{t},{ }^{2} J={ }^{3} \mathrm{~J}=\right.$ $\left.6.5 \mathrm{~Hz}, 1 \mathrm{H}, \mathrm{CH}_{2}-\mathrm{O}\right), 3.51\left(\mathrm{dd},{ }^{2} J=10.0,{ }^{3} J=5.5 \mathrm{~Hz}, 1 \mathrm{H}, \mathrm{OCH}-\right.$ $\left.\mathrm{CH}_{2}-\mathrm{O}\right), 3.48\left(\mathrm{~m}, 2 \mathrm{H}\right.$, OCH$\left.-\mathrm{CH}_{2}-\mathrm{O}\right), 3.44\left(\mathrm{dd},{ }^{2} \mathrm{~J}=10.0,{ }^{3} \mathrm{~J}=\right.$ $\left.6.0 \mathrm{~Hz}, 1 \mathrm{H}, \mathrm{OCH}-\mathrm{CH}_{2} \mathrm{O}\right), 1.40\left(\mathrm{~s}, 6 \mathrm{H}, \mathrm{CH}_{3}\right), 1.35(\mathrm{~s}, 6 \mathrm{H}$, $\left.\mathrm{CH}_{3}\right)$ ppm. ${ }^{13} \mathrm{C}$ NMR $\left(100 \mathrm{MHz}, \mathrm{CDCl}_{3}\right): \delta=155.4(\mathrm{C}=\mathrm{N}), 137.4$ (C-Ar), 128.4 (C-Ar), 128.1 (C-Ar), 127.9 (C-Ar), 109.4 (O-C-O), $76.3\left(\mathrm{CH}_{2}-\mathrm{Ar}\right), 74.5(\mathrm{CH}-\mathrm{O}), 72.3\left(\mathrm{CH}_{2}-\mathrm{O}\right), 71.4\left(\mathrm{CH}_{2}-\mathrm{O}\right), 68.7$ $\left(\mathrm{CH}_{2}-\mathrm{O}\right), 66.7\left(\mathrm{CH}_{2}-\mathrm{O}\right), 66.6\left(\mathrm{CH}_{2}-\mathrm{O}\right), 64.4\left(\mathrm{CH}_{2}-\mathrm{O}\right), 26.7\left(\mathrm{CH}_{3}\right)$, $25.4\left(\mathrm{CH}_{3}\right)$ ppm. $\mathrm{C}_{22} \mathrm{H}_{34} \mathrm{NO}_{7}$ (423.50): calcd. C 62.39, H 7.85, N 3.31 ; found $\mathrm{C} 62.58, \mathrm{H} 8.03, \mathrm{~N} 3.24$.

$(\boldsymbol{R}, \boldsymbol{R})-7 \mathrm{~b}$ : Yield $87 \%(795 \mathrm{mg})$. $[a]]_{\mathrm{D}}^{25}=-11.6\left(c=1.5, \mathrm{CHCl}_{3}\right)$.

$\left(\boldsymbol{S}^{*}, \boldsymbol{S}^{*}\right)$ - and $\left(\boldsymbol{S}^{*}, \boldsymbol{R}^{*}\right)-7 \mathrm{~b}$ : Yield $85 \%(780 \mathrm{mg})$.

2,8-Dihydroxymethyl-1,4,7,10-tetraoxaspiro[5.5]undecane (1): Amberlyst ${ }^{\circledR} 15(1.15 \mathrm{~g}, 250 \mathrm{mg} / \mathrm{mmol})$ was added to a solution of oxime $7 \mathrm{~b}(1.94 \mathrm{~g}, 4.59 \mathrm{mmol})$ in a mixture of acetone and water $(10: 1 \mathrm{v} /$ $\mathrm{v}, 33 \mathrm{~mL}$ ). The resulting solution was refluxed for $2 \mathrm{~d}$. After filtration of the insoluble material through a Celite ${ }^{\circledR}$ pad, the solvent was eliminated and the residue purified by $\mathrm{SiO}_{2}$ column chromatography $(\mathrm{EtOAc} / \mathrm{MeOH}, 49: 1)$ to give $1 \mathrm{a}$ as a white powder. The racemic product was obtained in $97 \%$ yield $(1.08 \mathrm{~g})$ as a $5: 3$ mixture of two isomers, $( \pm)-\left(2 R^{*}, 6 S^{*}, 8 R^{*}\right)-1 \mathrm{a}$ and $( \pm)-\left(2 R^{*}, 6 R^{*}, 8 S^{*}\right)-1 \mathbf{b}$, which could be separated by flash column chromatography $($ EtOAc/MeOH, 1:0 $\rightarrow$ 49:1).

$(2 R, 6 S, 8 R)-1 \mathrm{a}:$ Yield $78 \%(791 \mathrm{mg}) . R_{\mathrm{f}}=0.35(\mathrm{EtOAc} / \mathrm{MeOH}$, 9:1). M.p. $146{ }^{\circ} \mathrm{C}(\mathrm{EtOAc})$. $[a]_{\mathrm{D}}^{25}=+3.1(c=1.6, \mathrm{MeOH})$. IR $(\mathrm{KBr})$ : $\tilde{\mathrm{v}}=3430(\mathrm{OH}) \mathrm{cm}^{-1} .{ }^{1} \mathrm{H}$ NMR $\left(400 \mathrm{MHz}, \mathrm{CD}_{3} \mathrm{OD}\right): \delta=4.03(\mathrm{dtd}$, ${ }^{3} J=11.0,{ }^{3} J=5.0,{ }^{3} J=3.0 \mathrm{~Hz}, 2 \mathrm{H}, 2-\mathrm{H}^{\mathrm{ax}}$ and $\left.8-\mathrm{H}^{\mathrm{ax}}\right), 3.80(\mathrm{dd}$, 
${ }^{2} J=11.0,{ }^{3} J=3.0 \mathrm{~Hz}, 2 \mathrm{H}, 3-\mathrm{H}^{\circ \mathrm{q}}$ and $\left.9-\mathrm{H}^{\mathrm{eq}}\right), 3.55\left(\mathrm{~d},{ }^{2} J=11.5 \mathrm{~Hz}\right.$, $2 \mathrm{H}, 5-\mathrm{H}^{\mathrm{eq}}$ and $\left.11-\mathrm{H}^{\mathrm{eq}}\right), 3.55\left(\mathrm{dd},{ }^{2} J=12.0,{ }^{3} J=5.0 \mathrm{~Hz}, 2 \mathrm{H}\right.$, $\left.\mathrm{CH}_{2} \mathrm{OH}\right), 3.51\left(\mathrm{dd},{ }^{2} \mathrm{~J}=12.0,{ }^{3} \mathrm{~J}=5.0 \mathrm{~Hz}, 2 \mathrm{H}, \mathrm{CH}_{2} \mathrm{OH}\right), 3.37(\mathrm{t}$, ${ }^{2} J={ }^{3} J=11.0 \mathrm{~Hz}, 2 \mathrm{H}, 3-\mathrm{H}^{\text {ax }}$ and $\left.9-\mathrm{H}^{\mathrm{ax}}\right), 3.24\left(\mathrm{~d},{ }^{2} J=11.5 \mathrm{~Hz}, 2\right.$ $\mathrm{H}, 5-\mathrm{H}^{\mathrm{ax}}$ and $\left.11-\mathrm{H}^{\mathrm{ax}}\right) \mathrm{ppm} .{ }^{13} \mathrm{C}$ NMR $\left(100 \mathrm{MHz}, \mathrm{CD}_{3} \mathrm{OD}\right): \delta=$ 93.0 (C-6), 70.2 (C-2 and C-8), 69.6 (C-5 and C-11), 68.8 (C-3 and C-9), 62.9 (C-12 and C-13) ppm. HRMS (ESI): calcd. for $\mathrm{C}_{9} \mathrm{H}_{16} \mathrm{O}_{6} \mathrm{Na}$ : 243.0845 ; found $243.0855[\mathrm{M}+\mathrm{Na}]^{+}$.

$(2 S, 6 R, 8 S)$-1a: Yield $60 \%(600 \mathrm{mg}) .[a]_{\mathrm{B}}^{25}=-5.8(c=1.5, \mathrm{MeOH})$. $\left(\mathbf{2} \boldsymbol{R}^{*}, \mathbf{6} \boldsymbol{R}^{*}, \mathbf{8} \boldsymbol{S}^{*}\right)-1 \mathrm{~b}$ : Yield $36 \%(401 \mathrm{mg}) . R_{\mathrm{f}}=0.45(\mathrm{EtOAc} / \mathrm{MeOH}$, 9:1). M.p. $118^{\circ} \mathrm{C}$ (EtOAc). ${ }^{1} \mathrm{H}$ NMR ( $\left.400 \mathrm{MHz}, \mathrm{CD}_{3} \mathrm{OD}\right): \delta=4.22$ $\left(\mathrm{dtd},{ }^{3} J=11.5,{ }^{3} J=5.0,{ }^{3} J=3.0 \mathrm{~Hz}, 1 \mathrm{H}, 8-\mathrm{H}^{\mathrm{ax}}\right), 3.99\left(\mathrm{~d},{ }^{2} J=\right.$ $\left.12.0 \mathrm{~Hz}, 1 \mathrm{H}, 11-\mathrm{H}^{\mathrm{eq}}\right), 3.80\left(\mathrm{dd},{ }^{2} J=11.5,{ }^{3} J=3.0 \mathrm{~Hz}, 1 \mathrm{H}, 9-\right.$ $\left.\mathrm{H}^{\mathrm{eq}}\right), 3.78(\mathrm{~m}, 1 \mathrm{H}, 2-\mathrm{H}), 3.77\left(\mathrm{~m}, 1 \mathrm{H}, \mathrm{CH}_{2} \mathrm{OH}\right), 3.74\left(\mathrm{dd},{ }^{2} J=\right.$ $\left.11.5,{ }^{3} \mathrm{~J}=3.0 \mathrm{~Hz}, 1 \mathrm{H}, 3-\mathrm{H}^{\mathrm{eq}}\right), 3.69\left(\mathrm{~m}, 1 \mathrm{H}, \mathrm{CH}_{2} \mathrm{OH}\right), 3.57(\mathrm{dd}$, $\left.{ }^{2} J=11.5,{ }^{3} J=6.0 \mathrm{~Hz}, 1 \mathrm{H}, 3-\mathrm{H}^{\mathrm{ax}}\right), 3.50\left(\mathrm{dd},{ }^{2} J=11.5,{ }^{3} J=5.0 \mathrm{~Hz}\right.$, $\left.1 \mathrm{H}, \mathrm{CH}_{2} \mathrm{OH}\right), 3.48\left(\mathrm{~d},{ }^{2} J=11.5 \mathrm{~Hz}, 1 \mathrm{H}, 5-\mathrm{H}^{\mathrm{eq}}\right), 3.47\left(\mathrm{dd},{ }^{2} J=\right.$ $\left.11.5,{ }^{3} J=5.0 \mathrm{~Hz}, 1 \mathrm{H}, \mathrm{CH}_{2} \mathrm{OH}\right), 3.37\left(\mathrm{t},{ }^{2} J={ }^{3} J=11.5 \mathrm{~Hz}, 1 \mathrm{H}\right.$, 9- $\left.\mathrm{H}^{\mathrm{ax}}\right), 3.35\left(\mathrm{~d},{ }^{2} J=11.5 \mathrm{~Hz}, 1 \mathrm{H}, 5-\mathrm{H}^{\mathrm{ax}}\right), 3.23\left(\mathrm{~d},{ }^{2} J=12.0 \mathrm{~Hz}, 1\right.$ $\left.\mathrm{H}, 11-\mathrm{H}^{\mathrm{ax}}\right) \mathrm{ppm} .{ }^{13} \mathrm{C}$ NMR $\left(100 \mathrm{MHz}, \mathrm{CD}_{3} \mathrm{OD}\right): \delta=92.7(\mathrm{C}-6)$, 73.5 (C-2), 71.3 (C-5), 70.4 (C-8), 69.0 (C-9), 68.5 (C-11), 68.2 (C3), 62.9 (C-12), 62.8 (C-13) ppm.

( \pm )-(2,2-Dimethyl-1,3-dioxolan-4-yl)methanethiol (6): 3-Mercapto1,2-propanediol ( $3 \mathrm{~g}, 27.7 \mathrm{mmol})$ was dissolved in acetone $(40 \mathrm{~mL})$. Pyridinium $p$-toluenesulfonate $\left(700 \mathrm{mg}, 2.77 \mathrm{mmol}\right.$ ) and $\mathrm{MgSO}_{4}$ $(5 \mathrm{~g})$ were added. The mixture was stirred for $3 \mathrm{~d}$ at $20^{\circ} \mathrm{C}$ before being filtered through a Celite ${ }^{\circledR}$ pad. After elimination of the solvent, the residue was purified by flash column chromatography (pentane/ $\left.\mathrm{Et}_{2} \mathrm{O}, 24: 1\right)$ to afford the thiol $6(2.6 \mathrm{~g}, 17.7 \mathrm{mmol}, 64 \%$ ) as a colourless liquid.

[(4R)- or (4S)-2,2-Dimethyl-1,3-dioxolan-4-yl|methanethiol (6): A solution of toluene-p-sulfonyl chloride $(5.2 \mathrm{~g}, 27.2 \mathrm{mmol})$ in dry $\mathrm{CH}_{2} \mathrm{Cl}_{2}(30 \mathrm{~mL})$ was added to a solution of $(S)$ - or $(R)$-solketal $5(3 \mathrm{~g}, 22.7 \mathrm{mmol})$, DMAP (0.01 equiv., $28 \mathrm{mg}, 0.23 \mathrm{mmol})$ and triethylamine $(7.3 \mathrm{~mL}, 52.2 \mathrm{mmol})$ in dry $\mathrm{CH}_{2} \mathrm{Cl}_{2}(50 \mathrm{~mL})$ at $0{ }^{\circ} \mathrm{C}$. The flask was kept in a fridge for $2 \mathrm{~d}$. After dilution with $\mathrm{CH}_{2} \mathrm{Cl}_{2}$ $(225 \mathrm{~mL})$, the solution was washed twice with water $(45 \mathrm{~mL})$. After evaporation of the solvent, the residue was dissolved in diethyl ether $(75 \mathrm{~mL})$ and the organic layer was dried with $\mathrm{MgSO}_{4}$, filtered and concentrated under reduced pressure. The crude tosylate 9 was dissolved in acetone $(120 \mathrm{~mL})$ and potassium thioacetate $(2.95 \mathrm{~g}$, $25.8 \mathrm{mmol}$ ) was added. The resulting solution was refluxed for $24 \mathrm{~h}$. After filtration and concentration, the residue was treated with water $(20 \mathrm{~mL})$ and extracted with diethyl ether $(2 \times 100 \mathrm{~mL})$. The organic layer was dried with $\mathrm{MgSO}_{4}$, filtered and concentrated to give the thioacetate 10. This was dissolved in $\mathrm{EtOH}(3 \mathrm{~mL})$ and $5 \mathrm{~N} \mathrm{NaOH}(5.5 \mathrm{~mL}, 27.7 \mathrm{mmol})$ was added. The resulting solution was stirred for $9 \mathrm{~h}$ at $20^{\circ} \mathrm{C}$. The reaction was carefully neutralized with acetic acid and the EtOH was evaporated. After extraction with ether $(3 \times 10 \mathrm{~mL})$, the combined organic layers were washed with a saturated solution of $\mathrm{NaHCO}_{3}$, dried with $\mathrm{MgSO}_{4}$ and concentrated. The residue was finally purified by flash column chromatography $\left(\mathrm{C}_{5} \mathrm{H}_{12} / \mathrm{Et}_{2} \mathrm{O}, 24: 1\right)$ to afford $(R)$ - or $(S)-6$ as a colourless liquid:

(R)-6: Yield 75\% (2.52 g). $[a]_{\mathrm{D}}^{25}=+35.6\left(c=1.4, \mathrm{CHCl}_{3}\right) .{ }^{1} \mathrm{H}$ NMR $\left(400 \mathrm{MHz}, \mathrm{CDCl}_{3}\right): \delta=4.18\left(\mathrm{q},{ }^{3} J=6.0 \mathrm{~Hz}, 1 \mathrm{H}, \mathrm{CH}-\mathrm{O}\right), 4.08(\mathrm{dd}$, $\left.{ }^{2} J=8.0,{ }^{3} J=6.0 \mathrm{~Hz}, 1 \mathrm{H}, \mathrm{CH}_{2}-\mathrm{O}\right), 3.74\left(\mathrm{dd},{ }^{2} J=8.0,{ }^{3} J=6.0 \mathrm{~Hz}\right.$, $\left.1 \mathrm{H}, \mathrm{CH}_{2}-\mathrm{O}\right), 2.72\left(\mathrm{ddd},{ }^{2} J=13.5,{ }^{3} J=8.0,{ }^{3} \mathrm{~J}=6.0 \mathrm{~Hz}, 1 \mathrm{H}\right.$, $\mathrm{CH}_{2}$-S), 2.58 (ddd, ${ }^{2} J=13.5,{ }^{3} J=9.0,{ }^{3} J=6.0 \mathrm{~Hz}, 1 \mathrm{H}, \mathrm{CH}_{2}-\mathrm{S}$ ), $1.45\left(\mathrm{t},{ }^{3} \mathrm{~J}=8.5 \mathrm{~Hz}, 1 \mathrm{H}, \mathrm{SH}\right), 1.41\left(\mathrm{~s}, 3 \mathrm{H}, \mathrm{CH}_{3}\right), 1.34(\mathrm{~s}, 3 \mathrm{H}$, $\mathrm{CH}_{3}$ ) ppm. ${ }^{13} \mathrm{C}$ NMR $\left(100 \mathrm{MHz}, \mathrm{CDCl}_{3}\right): \delta=109.6$ (O-C-O), 76.9 (CH-O), $68.2\left(\mathrm{CH}_{2} \mathrm{O}\right), 27.6\left(\mathrm{CH}_{2} \mathrm{~S}\right), 26.8\left(\mathrm{CH}_{3}\right), 25.4\left(\mathrm{CH}_{3}\right) \mathrm{ppm}$.
(S)-6: Yield 52\% (1.78 g). [a] $]_{\mathrm{D}}^{55}=-31.1\left(c=1.4, \mathrm{CHCl}_{3}\right)$.

1,3-Bis|(4R)-2,2-dimethyl-1,3-dioxolan-4-ylmethylthio|propanone $O$ Benzyloxime (8): According to the procedure described for the preparation of $7 \mathrm{~b}$, starting from thiol $6(1.21 \mathrm{~g}, 8.17 \mathrm{mmol})$ and oxime 4 ( $860 \mathrm{mg}, 3.72 \mathrm{mmol}$ ), oxime 8 was obtained after purification by $\mathrm{SiO}_{2}$ column chromatography (cyclohexane/EtOAc, 9:1) as a colourless oil.

$(\boldsymbol{R}, \boldsymbol{R})-8$ : Yield $91 \%(1.55 \mathrm{~g}) .[a]]_{\mathrm{D}}^{25}=+22.6\left(c=1.4, \mathrm{CHCl}_{3}\right)$. IR $(\mathrm{NaCl}): \tilde{\mathrm{v}}=2985,2933,2876,1373,1253,1216,1153,1059,858$, $753,700 \mathrm{~cm}^{-1} .{ }^{1} \mathrm{H}$ NMR $\left(400 \mathrm{MHz}, \mathrm{CDCl}_{3}\right): \delta=7.37-7.28$ (m, 5 $\mathrm{H}$, Ar-H), 5.08 (s, $2 \mathrm{H}, \mathrm{Ar}-\mathrm{H}$ ), 4.22 (quint, ${ }^{3} J=6.0 \mathrm{~Hz}, 1 \mathrm{H}, \mathrm{CH}-$ O), 4.18 (quint, ${ }^{3} J=6.0 \mathrm{~Hz}, 1 \mathrm{H}, \mathrm{CH}-\mathrm{O}$ ), $4.00\left(\mathrm{dd},{ }^{2} J=6.0,{ }^{3} J=\right.$ $\left.2.0 \mathrm{~Hz}, 1 \mathrm{H}, \mathrm{CH}_{2}-\mathrm{O}\right), 3.97\left(\mathrm{dd},{ }^{2} J=6.0,{ }^{3} J=2.0 \mathrm{~Hz}, 1 \mathrm{H}, \mathrm{CH}_{2-}\right.$ O), 3.63-3.52 (m, $\left.4 \mathrm{H}, \mathrm{N}=\mathrm{C}-\mathrm{CH}_{2}-\mathrm{S}, \mathrm{CH}_{2}-\mathrm{O}\right), 3.37(\mathrm{~s}, 2 \mathrm{H}, \mathrm{N}=\mathrm{C}-$ $\left.\mathrm{CH}_{2}-\mathrm{S}\right), 2.69\left(\mathrm{dd},{ }^{2} J=13.5,{ }^{3} \mathrm{~J}=6.0 \mathrm{~Hz}, 1 \mathrm{H}, \mathrm{S}-\mathrm{CH}_{2}\right), 2.58\left(\mathrm{dd},{ }^{2} \mathrm{~J}\right.$ $\left.=13.5,{ }^{3} J=6.5 \mathrm{~Hz}, 1 \mathrm{H}, \mathrm{S}-\mathrm{CH}_{2}\right), 2.57\left(\mathrm{dd},{ }^{2} J=13.5,{ }^{3} \mathrm{~J}=6.5 \mathrm{~Hz}\right.$, $\left.1 \mathrm{H}, \mathrm{S}-\mathrm{CH}_{2}\right), 2.46\left(\mathrm{dd},{ }^{2} J=13.5,{ }^{3} J=6.5 \mathrm{~Hz}, 1 \mathrm{H}, \mathrm{S}-\mathrm{CH}_{2}\right), 1.42$ (s, $\left.3 \mathrm{H}, \mathrm{CH}_{3}\right), 1.41\left(\mathrm{~s}, 3 \mathrm{H}, \mathrm{CH}_{3}\right), 1.35\left(\mathrm{~s}, 3 \mathrm{H}, \mathrm{CH}_{3}\right), 1.33$ (s, $3 \mathrm{H}$, $\left.\mathrm{CH}_{3}\right)$ ppm. ${ }^{13} \mathrm{C}$ NMR $\left(100 \mathrm{MHz}, \mathrm{CDCl}_{3}\right): \delta=154.1(\mathrm{CN}), 137.4$ (C-Ar), 128.4 (C-Ar), 128.3 (C-Ar), 128.0 (C-Ar), 109.6 (O-C-O), $76.2\left(\mathrm{CH}_{2}-\mathrm{Ar}\right), 74.9(\mathrm{CH}-\mathrm{O}), 68.7\left(\mathrm{CH}_{2}-\mathrm{O}\right), 35.2\left(\mathrm{CH}_{2}-\mathrm{S}\right), 34.1$ $\left(\mathrm{CH}_{2}-\mathrm{S}\right), 33.1\left(\mathrm{~S}-\mathrm{CH}_{2}\right), 26.9\left(\mathrm{CH}_{3}\right), 25.5\left(\mathrm{CH}_{3}\right), 25.1\left(\mathrm{~S}^{-\mathrm{CH}_{2}}\right) \mathrm{ppm}$. $\mathrm{C}_{22} \mathrm{H}_{33} \mathrm{NO}_{5} \mathrm{~S}_{2}$ (455.63): calcd. C 57.99, H 7.30, N 3.07, S 14.08; found $\mathrm{C} 58.30, \mathrm{H} 7.47, \mathrm{~N} 3.11, \mathrm{~S} 13.93$.

$(S, S)-8$ : Yield $90 \%(1.52 \mathrm{~g})$. $[a]_{\mathrm{D}}^{5}=-25.8\left(c=1.5, \mathrm{CHCl}_{3}\right)$.

$\left(\boldsymbol{R}^{*}, \boldsymbol{R}^{*}\right)$ - and $\left(\boldsymbol{R}^{*}, \boldsymbol{S}^{*}\right)$-8: Yield 83\% $(1.41 \mathrm{~g})$.

General Procedure for the Cyclization of 8: Amberlyst ${ }^{\mathbb{Q}} 15(250 \mathrm{mg})$ and paraformaldehyde $(10 \mathrm{mmol})$ were added to a solution of oxime $8(1 \mathrm{mmol})$ in acetone $(10 \mathrm{~mL})$ and water $(1 \mathrm{~mL})$. The resulting mixture was refluxed for $2 \mathrm{~d}$. After removing insoluble material by filtration through a Celite ${ }^{\mathbb{B}}$ pad, the solvent was evaporated. The residue was purified by $\mathrm{SiO}_{2}$ column chromatography (EtOAc/cyclohexane, 9:1).

General Procedure for TBDPS Protection of 2: Imidazole ( $4.4 \mathrm{mmol})$ followed by tert-butylchlorodiphenylsilane $(2.2 \mathrm{mmol})$ were added at $0{ }^{\circ} \mathrm{C}$ to a mixture of $2(1 \mathrm{mmol})$ in DMF $(5 \mathrm{~mL})$. The resulting solution was stirred overnight and then taken up in diethyl ether $(100 \mathrm{~mL})$ and the organic layer was washed with water $(15 \mathrm{~mL})$ followed by a saturated aqueous $\mathrm{NH}_{4} \mathrm{Cl}$ solution $(15 \mathrm{~mL})$. Filtration and evaporation of the dried $\left(\mathrm{MgSO}_{4}\right)$ organic layer afforded derivatives 11 which could be separated by two consecutive flash column chromatography (cyclohexane/EtOAc, 49:1 then cyclohexane/Et $\left.{ }_{2} \mathrm{O}, 100: 1 \rightarrow 50: 1\right)$

General Procedure for TPDPS Cleavage of 11: Tetrabutylammonium fluoride ( $1.0 \mathrm{M}$ in THF, $2.4 \mathrm{mmol}$ ) was added to a solution of TBDPS-protected spirocompound $11(1 \mathrm{mmol})$ in anhydrous THF $(5 \mathrm{~mL})$. After stirring at $20^{\circ} \mathrm{C}$ overnight, the reaction mixture was diluted with ethyl acetate $(100 \mathrm{~mL})$ and then washed with water $(10 \mathrm{~mL})$ followed by brine $(10 \mathrm{~mL})$. The organic layer was dried with $\mathrm{MgSO}_{4}$. The solvent was evaporated and the residue was purified by $\mathrm{SiO}_{2}$ column chromatography (EtOAc/cyclohexane, 4:1).

$(2 R, 6 S, 8 R)$ - and $(2 R, 6 R, 8 R)$-2,8-Dihydroxymethyl-1,7-dioxa-4,10dithiaspiro|5.5/undecane (2a) and (2b): According to the general procedure of cyclization, starting from $(R, R)$-oxime 8, an inseparable mixture of $(2 R, 6 S, 8 R)-2 \mathbf{a}$ and $(2 R, 6 R, 8 R)$-2 $\mathbf{b}$ was obtained in a $10: 7$ ratio and $75 \%$ yield. The isomers were separated by preparing their TBDPS derivatives 11a and 11b using the general procedure of protection followed by deprotection under the conditions described in the general procedure.

(2R,6S,8R)-11a: Viscous oil. $R_{\mathrm{f}}=0.74$ (cyclohexane/EtOAc, 9:1). $[a]_{\mathrm{D}}^{25}=-76.0\left(c=1.2, \mathrm{CHCl}_{3}\right) .{ }^{1} \mathrm{H}$ NMR $\left(400 \mathrm{MHz}, \mathrm{CDCl}_{3}\right): \delta=$ 
$7.73(\mathrm{~m}, 8 \mathrm{H}, \mathrm{Ar}-\mathrm{H}), 7.39(\mathrm{~m}, 12 \mathrm{H}, \mathrm{Ar}-\mathrm{H}), 4.16\left(\mathrm{dtd},{ }^{3} J=11.0\right.$ ${ }^{3} J=5.5,{ }^{3} J=2.0 \mathrm{~Hz}, 2 \mathrm{H}, 2-\mathrm{H}^{\text {ax }}$ and $\left.8-\mathrm{H}^{\mathrm{ax}}\right), 3.76\left(\mathrm{dd},{ }^{2} J=10.5\right.$, $\left.{ }^{3} J=5.5 \mathrm{~Hz}, 2 \mathrm{H}, \mathrm{CH}_{2} \mathrm{OSi}\right), 3.60\left(\mathrm{dd},{ }^{2} J=10.5,{ }^{3} J=5.5 \mathrm{~Hz}, 2 \mathrm{H}\right.$, $\left.\mathrm{CH}_{2} \mathrm{OSi}\right), 2.76\left(\mathrm{~d},{ }^{2} \mathrm{~J}=13.5 \mathrm{~Hz}, 2 \mathrm{H}, 5-\mathrm{H}\right.$ and $\left.11-\mathrm{H}\right), 2.58\left(\mathrm{dd},{ }^{2} \mathrm{~J}\right.$ $=13.0,{ }^{3} J=11.0 \mathrm{~Hz}, 2 \mathrm{H}, 3-\mathrm{H}^{\mathrm{ax}}$ and $\left.9-\mathrm{H}^{\mathrm{ax}}\right), 2.44\left(\mathrm{~d},{ }^{2} J=13.0 \mathrm{~Hz}\right.$, $2 \mathrm{H}, 3-\mathrm{H}^{\mathrm{eq}}$ and $\left.9-\mathrm{H}^{\mathrm{eq}}\right), 2.40\left(\mathrm{~d},{ }^{2} J=13.5 \mathrm{~Hz}, 2 \mathrm{H}, 5-\mathrm{H}\right.$ and $\left.11-\mathrm{H}\right)$, $1.07\left(\mathrm{~s}, 18 \mathrm{H}, \mathrm{CH}_{3}\right)$ ppm. ${ }^{13} \mathrm{C}$ NMR $\left(100 \mathrm{MHz}, \mathrm{CDCl}_{3}\right): \delta=135.7$ (C-Ar), 133.2 (C-Ar), 129.7 (C-Ar), 127.7 (C-Ar), 127.6 (C-Ar), 90.4 (C-6), $70.6(\mathrm{C}-2$ and $\mathrm{C}-8), 66.5\left(\mathrm{CH}_{2} \mathrm{OSi}\right), 34.6(\mathrm{C}-5$ and $\mathrm{C}-11)$, 27.3 (C-3 and C-9), $26.8\left(\mathrm{CH}_{3}\right), 19.2\left[\mathrm{C}\left(\mathrm{CH}_{3}\right)_{3}\right] \mathrm{ppm}$. MS (ESI): $\mathrm{m} / \mathrm{z}$ $(\%)=767(53)[\mathrm{M}+\mathrm{K}]^{+}, 751(100)[\mathrm{M}+\mathrm{Na}]^{+}, 288(22)$.

$(2 R, 6 R, 8 R)-11 b$ : Viscous oil. $R_{\mathrm{f}}=0.48$ (cyclohexane/EtOAc, 9:1). $[a]]^{5}=-2.2\left(c=3.0, \mathrm{CHCl}_{3}\right) .{ }^{1} \mathrm{H}$ NMR $\left(400 \mathrm{MHz}, \mathrm{CDCl}_{3}\right): \delta=$ 7.26-7.68 (m, $20 \mathrm{H}, \mathrm{Ar}), 4.65$ (br. d, $\left.{ }^{3} J=5.0 \mathrm{~Hz}, 1 \mathrm{H}, 8-\mathrm{H}\right), 4.30$ $\left(\mathrm{d},{ }^{2} \mathrm{~J}=6.0 \mathrm{~Hz}, 1 \mathrm{H}, \mathrm{CH}_{2} \mathrm{OSi}\right), 3.93\left(\mathrm{qd},{ }^{3} \mathrm{~J}=5.0,{ }^{3} J=7.0 \mathrm{~Hz}, 2\right.$ $\mathrm{H}, 2-\mathrm{H}), 3.87\left(\mathrm{dd},{ }^{2} J=6.0 \mathrm{~Hz},{ }^{3} J=7.0 \mathrm{~Hz}, 1 \mathrm{H}, \mathrm{CH}_{2} \mathrm{OSi}\right), 3.74$ (dd, ${ }^{2} J=10.5,{ }^{3} J=5.0 \mathrm{~Hz}, 1 \mathrm{H}, \mathrm{CH}_{2} \mathrm{OSi}$ ), $3.71\left(\mathrm{dd},{ }^{2} J=10.5,{ }^{3} \mathrm{~J}\right.$ $=5.0 \mathrm{~Hz}, 1 \mathrm{H}, \mathrm{CH}_{2} \mathrm{OSi}$ ), 3.14 (br. d, ${ }^{2} J=13.0 \mathrm{~Hz}, 1 \mathrm{H}, 9-\mathrm{H}^{\mathrm{ax}}$ ), $2.98\left(\mathrm{dd},{ }^{2} J=13.5,{ }^{3} J=7.0 \mathrm{~Hz}, 1 \mathrm{H}, 3-\mathrm{H}^{\mathrm{a}}\right), 2.91\left(\mathrm{~d},{ }^{2} J=13.0 \mathrm{~Hz}\right.$, $1 \mathrm{H}, 11-\mathrm{H}), 2.66\left(\mathrm{dd},{ }^{2} J=13.5,{ }^{3} J=5.0 \mathrm{~Hz}, 1 \mathrm{H}, 3-\mathrm{H}^{\mathrm{eq}}\right), 2.55(\mathrm{~d}$, $\left.{ }^{2} J=14.0 \mathrm{~Hz}, 1 \mathrm{H}, 5-\mathrm{H}\right), 2.50\left(\mathrm{~d},{ }^{2} J=14.0 \mathrm{~Hz}, 1 \mathrm{H}, 5-\mathrm{H}\right), 2.33(\mathrm{~d}$, $\left.{ }^{2} J=13.0 \mathrm{~Hz}, 1 \mathrm{H}, 11-\mathrm{H}\right), 2.11\left(\mathrm{dd},{ }^{2} J=13.0,{ }^{3} J=2.0 \mathrm{~Hz}, 1 \mathrm{H}, 9\right.$ $\left.\mathrm{H}^{\mathrm{oq}}\right), 1.04\left(\mathrm{~s}, 9 \mathrm{H}, \mathrm{CH}_{3}\right), 1.01\left(\mathrm{~s}, 9 \mathrm{H}, \mathrm{CH}_{3}\right) \mathrm{ppm} .{ }^{13} \mathrm{C} \mathrm{NMR}$ $\left(100 \mathrm{MHz}, \mathrm{CDCl}_{3}\right): \delta=136.0(\mathrm{C}-\mathrm{Ar}), 135.8(\mathrm{C}-\mathrm{Ar}), 135.6$ (C-Ar), 135.5 (C-Ar), 133.9 (C-Ar), 133.8 (C-Ar), 133.5 (C-Ar), 133.4 (CAr), 129.6 (C-Ar), 129.5 (C-Ar), 127.6 (C-Ar), 127.5 (C-Ar), 106.8 (C-6), $74.6(\mathrm{C}-8), 73.1(\mathrm{C}-2), 69.5\left(\mathrm{CH}_{2} \mathrm{OSi}\right), 65.4\left(\mathrm{CH}_{2} \mathrm{OSi}\right), 39.7$ (C-5), 36.5 (C-3), 33.1 (C-11), 28.9 (C-9), $26.9\left(\mathrm{CH}_{3}\right), 26.8\left(\mathrm{CH}_{3}\right)$, 19.2

$\left[C\left(\mathrm{CH}_{3}\right)_{3}\right] \mathrm{ppm}$. MS (ESI): $m / z(\%)=767(13)[\mathrm{M}+\mathrm{K}]^{+}, 751(18)$ $[\mathrm{M}+\mathrm{Na}]^{+}, 288(100)$.

(2R,6S,8R)-2a: White solid. $R_{\mathrm{f}}=0.37$ (EtOAc). $[a]_{\mathrm{D}}^{25}=-137.5(c=$ 0.6, $\left.\mathrm{CH}_{3} \mathrm{OH}\right)$. M.p. $98^{\circ} \mathrm{C}$ (EtOAc). ${ }^{1} \mathrm{H}$ NMR $\left(400 \mathrm{MHz}, \mathrm{CD}_{3} \mathrm{OD}\right)$ : $\delta=3.97\left(\mathrm{dt},{ }^{3} J=11.5,{ }^{3} J=5.0 \mathrm{~Hz}, 2 \mathrm{H}, 2-\mathrm{H}^{\mathrm{ax}}\right.$ and $\left.8-\mathrm{H}^{\mathrm{ax}}\right), 3.56$ $\left(\mathrm{dd},{ }^{2} J=11.5,{ }^{3} \mathrm{~J}=5.0 \mathrm{~Hz}, 2 \mathrm{H}, \mathrm{CH}_{2} \mathrm{OH}\right), 3.48\left(\mathrm{dd},{ }^{2} \mathrm{~J}=11.5,{ }^{3} \mathrm{~J}\right.$ $\left.=5.0 \mathrm{~Hz}, 2 \mathrm{H}, \mathrm{CH}_{2} \mathrm{OH}\right), 2.76\left(\mathrm{~d},{ }^{2} J=13.5 \mathrm{~Hz}, 2 \mathrm{H}, 5-\mathrm{H}\right.$ and $11-$ $\mathrm{H}), 2.54\left(\mathrm{t},{ }^{2} J={ }^{3} J=11.5 \mathrm{~Hz}, 2 \mathrm{H}, 3-\mathrm{H}^{\mathrm{ax}}\right.$ and $\left.9-\mathrm{H}^{\mathrm{ax}}\right), 2.40\left(\mathrm{~d},{ }^{2} J\right.$ $=13.5 \mathrm{~Hz}, 2 \mathrm{H}, 5-\mathrm{H}$ and $11-\mathrm{H}), 2.37\left(\mathrm{~d},{ }^{2} J=11.5 \mathrm{~Hz}, 2 \mathrm{H}, 3-\mathrm{H}^{\mathrm{eq}}\right.$ and $9-\mathrm{H}^{\mathrm{eq}}$ ) ppm. ${ }^{13} \mathrm{C}$ NMR (100 MHz, $\left.\mathrm{CD}_{3} \mathrm{OD}\right): \delta=91.9$ (C-6), $72.4(\mathrm{C}-2$ and $\mathrm{C}-8), 65.9\left(\mathrm{CH}_{2} \mathrm{OH}\right), 35.2(\mathrm{C}-5$ and $\mathrm{C}-11), 27.8(\mathrm{C}-$ 3 and C-9) ppm. $\mathrm{C}_{9} \mathrm{H}_{16} \mathrm{O}_{4} \mathrm{~S}_{2}(252.35)$ : calcd. C 42.84, H 6.39, S 25.41; found C 42.67, H 6.36, S 25.54

(2R,6R,8R)-2b: Colourless oil. $R_{\mathrm{f}}=0.37$ (EtOAc). ${ }^{1} \mathrm{H}$ NMR ( $400 \mathrm{MHz}, \mathrm{CD}_{3} \mathrm{OD}$ ): $\delta=4.77$ (br. d, ${ }^{3} J=6.0 \mathrm{~Hz}, 1 \mathrm{H}, 8-\mathrm{H}^{\mathrm{eq}}$ ), 4.33 (d, $\left.{ }^{2} J=6.5 \mathrm{~Hz}, 1 \mathrm{H}, \mathrm{CH}_{2} \mathrm{OH}\right), 3.94\left(\mathrm{t},{ }^{2} J={ }^{3} J=6.0 \mathrm{~Hz}, 1 \mathrm{H}\right.$, $\left.\mathrm{CH}_{2} \mathrm{OH}\right), 3.71\left(\mathrm{dq},{ }^{3} \mathrm{~J}=7.0,{ }^{3} J={ }^{3} J_{2,3 \mathrm{~b}}=5.0 \mathrm{~Hz}, 1 \mathrm{H}, 2-\mathrm{H}\right), 3.54$ $\left(\mathrm{dd},{ }^{2} J=11.0,{ }^{3} \mathrm{~J}=5.0 \mathrm{~Hz}, 1 \mathrm{H}, \mathrm{CH}_{2} \mathrm{OH}\right), 3.49\left(\mathrm{dd},{ }^{2} J=11.0,{ }^{3} \mathrm{~J}\right.$ $\left.=5.5 \mathrm{~Hz}, 1 \mathrm{H}, \mathrm{CH}_{2} \mathrm{OH}\right), 3.11\left(\mathrm{~d},{ }^{2} J=13.0 \mathrm{~Hz}, 1 \mathrm{H}, 9-\mathrm{H}^{\mathrm{ax}}\right), 3.01$ $\left(\mathrm{d},{ }^{2} J=13.0 \mathrm{~Hz}, 1 \mathrm{H}, 11-\mathrm{H}^{\mathrm{ax}}\right), 2.84\left(\mathrm{~d},{ }^{2} J=14.0 \mathrm{~Hz}, 1 \mathrm{H}, 5-\mathrm{H}^{\mathrm{a}}\right)$, $2.83\left(\mathrm{~d},{ }^{2} J=14.0 \mathrm{~Hz}, 1 \mathrm{H}, 5-\mathrm{H}^{\mathrm{b}}\right), 2.77\left(\mathrm{dd},{ }^{2} J=13.5,{ }^{3} J=5.5 \mathrm{~Hz}\right.$ $\left.1 \mathrm{H}, 3-\mathrm{H}^{\mathrm{a}}\right), 2.64\left(\mathrm{ddd},{ }^{2} J=13.5,{ }^{3} J_{3.2}=7.0,{ }^{4} \mathrm{~J}=2.0 \mathrm{~Hz}, 1 \mathrm{H}, 3-\right.$ $\left.\mathrm{H}^{\mathrm{b}}\right), 2.44\left(\mathrm{~d},{ }^{2} J=13.0 \mathrm{~Hz}, 1 \mathrm{H}, 11-\mathrm{H}^{\mathrm{eq}}\right), 2.19\left(\mathrm{~d},{ }^{2} J=13.0 \mathrm{~Hz}, 1\right.$ $\mathrm{H}, 9-\mathrm{H}^{\mathrm{eq}}$ ) ppm. ${ }^{13} \mathrm{C}$ NMR (100 MHz, $\left.\mathrm{CD}_{3} \mathrm{OD}\right): \delta=108.3$ (C-6), $76.3(\mathrm{C}-8), 72.9(\mathrm{C}-2), 70.8\left(\mathrm{CH}_{2} \mathrm{OH}\right), 66.0\left(\mathrm{CH}_{2} \mathrm{OH}\right), 40.6(\mathrm{C}-5)$, 37.8 (C-3), 33.9 (C-11), 29.7 (C-9) ppm.

(2S,6R,8S)- and (2S,6S,8S)-2,8-Dihydroxymethyl-1,7-dioxa-4,10-dithia-spiro|5.5/undecane (2a) and (2b): The general procedure applied to $(S, S)$-oxime 8 led to the isomers $(2 S, 6 R, 8 S)$-2a and $(2 S, 6 S, 8 S)$ 2b in a 10:7 ratio.

(2S,6R,8S)-11a: $[a]_{\mathrm{D}}^{25}=+62.8\left(c=1.1, \mathrm{CHCl}_{3}\right)$.

$(2 S, 6 S, 8 S)-11 \mathrm{~b}:[a]_{\mathrm{D}}^{25}=+2.7\left(c=0.3, \mathrm{CHCl}_{3}\right)$.
$(2 S, 6 R, 8 S)-2 \mathrm{a}:[a]_{\mathrm{D}}^{25}=+137.2\left(c=0.8, \mathrm{CH}_{3} \mathrm{OH}\right)$, m.p. $95^{\circ} \mathrm{C}$ (EtOAc).

$(2 S, 6 S, 8 S)-2 b:[a]_{\mathrm{B}}^{25}=+33.3\left(c=1.0, \mathrm{CH}_{3} \mathrm{OH}\right)$.

$\left(2 R^{*}, 6 S^{*}, 8 R^{*}\right)-, \quad\left(2 R^{*}, 6 R^{*}, 8 R^{*}\right)-, \quad\left(2 R^{*}, 6 S^{*}, 8 S^{*}\right)-\quad$ and $\left(2 R^{*}, 6 R^{*}, 8 S^{*}\right)-2,8$-Dihydroxymethyl-1,7-dioxa-4,10-dithiaspiro[5.5] undecane (2): The general cyclization conditions applied to $\left(R^{*}, R^{*}\right)$ - and $\left(R^{*}, S^{*}\right)-8$ gave a mixture of four diastereoisomers: $\left(2 R^{*}, 6 S^{*}, 8 R^{*}\right)-2 \mathbf{a},\left[\left(2 R^{*}, 6 R^{*}, 8 R^{*}\right)-\mathbf{2 b}+\left(2 R^{*}, 6 S^{*}, 8 S^{*}\right)-2 \mathrm{c}\right]$ and $\left(2 R^{*}, 6 R^{*}, 8 S^{*}\right)-2 \mathbf{d}$ in a $5: 7: 1$ ratio. Isomer $\left(2 R^{*}, 6 R^{*}, 8 S^{*}\right)-2 \mathbf{d}$ was directly isolated from the others by $\mathrm{SiO}_{2}$ column chromatography (EtOAc/cyclohexane, 9:1). Isomer 2a was obtained after TBDPS protection followed by cleavage. $\left(2 R^{*}, 6 R^{*}, 8 R^{*}\right)-\mathbf{2 b}$ and $\left(2 R^{*}, 6 S^{*}, 8 S^{*}\right)-2 \mathrm{c}$ could not be separated even with TBDPS protection.

$\left(2 R^{*}, \mathbf{6} \boldsymbol{R}^{*}, \mathbf{8} S^{*}\right)-2 \mathrm{~d}$ : Colourless oil. $R_{\mathrm{f}}=0.46$ (EtOAc). ${ }^{1} \mathrm{H}$ NMR $\left(400 \mathrm{MHz}, \mathrm{CD}_{3} \mathrm{OD}\right): \delta=4.36\left(\mathrm{dtd},{ }^{3} J=5.0,{ }^{3} J=11.0,{ }^{3} J=2.0 \mathrm{~Hz}\right.$ $1 \mathrm{H}, 8-\mathrm{H}), 3.81\left(\mathrm{dddd},{ }^{3} J=5.0,{ }^{3} J=6.0,{ }^{3} J=10.5,{ }^{3} J=2.0 \mathrm{~Hz}, 1\right.$ $\mathrm{H}, 2-\mathrm{H}), 3.61\left(\mathrm{dd},{ }^{2} J=11.0,{ }^{3} J=5.0 \mathrm{~Hz}, 1 \mathrm{H}, \mathrm{CH}_{2} \mathrm{OH}\right), 3.58(\mathrm{dd}$, $\left.{ }^{2} J=14.5,{ }^{4} J=2.0 \mathrm{~Hz}, 1 \mathrm{H}, 11-\mathrm{H}^{\mathrm{eq}}\right), 3.53\left(\mathrm{dd},{ }^{2} J=11.0,{ }^{3} J=\right.$ $\left.6.0 \mathrm{~Hz}, 1 \mathrm{H}, \mathrm{CH}_{2} \mathrm{OH}\right), 3.47\left(\mathrm{dd},{ }^{2} J=11.0,{ }^{3} \mathrm{~J}=5.0 \mathrm{~Hz}, 1 \mathrm{H}\right.$, $\left.\mathrm{CH}_{2} \mathrm{OH}\right), 3.41\left(\mathrm{dd},{ }^{2} J=11.0,{ }^{3} \mathrm{~J}=5.0 \mathrm{~Hz}, 1 \mathrm{H}, \mathrm{CH}_{2} \mathrm{OH}\right), 2.69(\mathrm{~d}$, $\left.{ }^{2} J=13.5 \mathrm{~Hz}, 1 \mathrm{H}, 5-\mathrm{H}^{\mathrm{eq}}\right), 2.64$ (d, $\left.{ }^{2} J=14.5 \mathrm{~Hz}, 1 \mathrm{H}, 11-\mathrm{H}^{\mathrm{ax}}\right), 2.55$ $\left(\mathrm{dd},{ }^{2} J=13.0,{ }^{3} J=11.0 \mathrm{~Hz} 1 \mathrm{H}, 9-\mathrm{H}^{\mathrm{ax}}\right), 2.54\left(\mathrm{dd},{ }^{2} J=13.5,{ }^{3} J=\right.$ $\left.10.5 \mathrm{~Hz}, 1 \mathrm{H}, 3-\mathrm{H}^{\mathrm{ax}}\right), 2.42$ (br. d, $\left.{ }^{2} J=13.5 \mathrm{~Hz}, 2 \mathrm{H}, 3-\mathrm{H}^{\mathrm{eq}}\right), 2.42$ $\left(\mathrm{d},{ }^{2} J=13.5 \mathrm{~Hz}, 1 \mathrm{H}, 5-\mathrm{H}^{\mathrm{ax}}\right), 2.37\left(\mathrm{dt},{ }^{2} J=13.0,{ }^{3} \mathrm{~J}=2.0,{ }^{4} \mathrm{~J}=\right.$ $\left.2.0 \mathrm{~Hz}, 1 \mathrm{H}, 9-\mathrm{H}^{\text {eq }}\right) \mathrm{ppm} .{ }^{13} \mathrm{C} \mathrm{NMR}\left(100 \mathrm{MHz}, \mathrm{CD}_{3} \mathrm{OD}\right): \delta=94.7$ (C-6), $76.3(\mathrm{C}-8), 72.1(\mathrm{C}-2), 66.0\left(\mathrm{CH}_{2} \mathrm{OH}\right), 65.9\left(\mathrm{CH}_{2} \mathrm{OH}\right), 35.9$ (C-11), 29.7 (C-3), 28.7 (C-5), 28.3 (C-9) ppm.

$(2 R, 6 S, 8 S)$ - and $(2 R, 6 R, 8 S)$-2,8-Dihydroxymethyl-1,7-dioxa-4,10dithiaspiro|5.5|undecane (2c and 2d): The general procedure of cyclization applied to $(R, S)-\mathbf{8}$ led to isomers $(2 R, 6 S, 8 S)-2 \mathrm{c}$ and $(2 R, 6 R, 8 S)$-2d with isomer $2 \mathrm{c}$ as the major compound.

$(2 R, 6 S, 8 S)-2 \mathrm{c}$ : Colourless oil. $R_{\mathrm{f}}=0.37$ (EtOAc). $\left.[a]\right]_{\mathrm{B}}^{5}=+10.0(c$ $\left.=0.1, \mathrm{CH}_{3} \mathrm{OH}\right) .{ }^{1} \mathrm{H}$ NMR $\left(400 \mathrm{MHz}, \mathrm{CD}_{3} \mathrm{OD}\right): \delta=4.75$ (br. d, ${ }^{3} \mathrm{~J}$ $\left.=6.0 \mathrm{~Hz}, 1 \mathrm{H}, 8-\mathrm{H}^{\mathrm{eq}}\right), 4.31\left(\mathrm{~d},{ }^{2} J=6.5 \mathrm{~Hz}, 1 \mathrm{H}, \mathrm{CH}_{2} \mathrm{OH}\right), 3.93(\mathrm{t}$, $\left.{ }^{2} J={ }^{3} J=6.0 \mathrm{~Hz}, 1 \mathrm{H}, \mathrm{CH}_{2} \mathrm{OH}\right), 3.69\left(\mathrm{dq},{ }^{3} J=7.0,{ }^{3} J=5.0 \mathrm{~Hz}, 1\right.$ $\mathrm{H}, 2-\mathrm{H}), 3.52\left(\mathrm{dd},{ }^{2} J=11.0,{ }^{3} \mathrm{~J}=5.5 \mathrm{~Hz}, 1 \mathrm{H}, \mathrm{CH}_{2} \mathrm{OH}\right), 3.47(\mathrm{dd}$, ${ }^{2} J=11.0,{ }^{3} J=5.0 \mathrm{~Hz}, 1 \mathrm{H}, \mathrm{CH}, \mathrm{OH}$ ), 3.09 (br. d, ${ }^{2} J=13.0 \mathrm{~Hz}, 1 \mathrm{H}$, 9- $\left.\mathrm{H}^{\mathrm{ax}}\right), 2.99\left(\mathrm{~d},{ }^{2} J=13.0 \mathrm{~Hz}, 1 \mathrm{H}, 11-\mathrm{H}^{\mathrm{ax}}\right), 2.83\left(\mathrm{~d},{ }^{2} J=15.0 \mathrm{~Hz}, 1\right.$ $\left.\mathrm{H}, 5-\mathrm{H}^{\mathrm{a}}\right), 2.80\left(\mathrm{~d},{ }^{2} J=15.0 \mathrm{~Hz}, 1 \mathrm{H}, 5-\mathrm{H}^{\mathrm{b}}\right), 2.75\left(\mathrm{dd},{ }^{2} J=13.5,{ }^{3} J\right.$ $\left.=5.0 \mathrm{~Hz}, 1 \mathrm{H}, 3-\mathrm{H}^{\mathrm{a}}\right), 2.63\left(\mathrm{dd},{ }^{2} J=13.5,{ }^{3} J=7.0 \mathrm{~Hz}, 1 \mathrm{H}, 3-\mathrm{H}^{\mathrm{b}}\right)$, $2.42\left(\mathrm{~d},{ }^{2} J=13.0 \mathrm{~Hz}, 1 \mathrm{H}, 11-\mathrm{H}^{\mathrm{eq}}\right), 2.18$ (br. d, ${ }^{2} J=13.0 \mathrm{~Hz}, 1 \mathrm{H}$, 9- $\left.\mathrm{H}^{\mathrm{eq}}\right)$ ppm. ${ }^{13} \mathrm{C}$ NMR (100 MHz, CD $\left.\mathrm{OD}\right): \delta=108.3(\mathrm{C}-6), 76.3$ (C-8), 72.9 (C-2), $70.8\left(\mathrm{CH}_{2} \mathrm{OH}\right), 66.0\left(\mathrm{CH}_{2} \mathrm{OH}\right), 40.6(\mathrm{C}-5), 37.8$ (C-3), 33.9 (C-11), 29.7 (C-9) ppm.

\section{Acknowledgments}

The authors thank Anne-Sophie Martin for performing the NOESY experiments. This research was supported by a grant from the Ministère de l'Enseignement Supérieur et de la Recherche (M.G.).

[1] For example, see: a) Y. Qtu, A. Hübener, H. Zhang, C. J. Moore, M. T. Fletcher, P. Hayes, K. Dettner, W. Francke, C. S. P. McErlean, W. Kitching, Synthesis 2000, 13, 1956-1978; b) W. Francke, W. Kitching, Curr. Org. Chem. 2001, 5, 233 251.

[2] For example, see: a) M. M. Faul, B. E. Huff, Chem. Rev. 2000, 100,2407-2473; b) J. A. Marshall, M. M. Yanik, J. Org. Chem. 2001, 66, 1373-1379. 
[3] For example, see: a) E. Hamel, Med. Res. Rev. 1996, 16, 207 231; b) F. M. Uckun, C. Mao, A. O. Vassilev, H. Huang, S. T Jan, Bioorg. Med. Chem. Lett. 2000, 10, 541-545; c) O. Barun, K. Kumar, S. Sommer, A. Lgerak, T. U. Mayer, O. Müller, H Waldmann, Eur. J. Org. Chem. 2005, 22, 4773-4788; for inhibitors of the mitogenic activity of epidermal growth factors (EGF), see: d) T. Takahashi, H. Osada, H. Koshino, M. Sasaki, R. Onose, M. Nakakoshi, M. Yoshihama, K. Isono, J. Antibiot. 1992, 45, 1414-1419; e) H. Takahashi, Y. Yamashita, H Takaoka, J. Nakamura, M. Yoshihama, H. Osada, Oncol. Res. $1997,9,7-11$; for new apoptosis-inducing agents, see: f) S. Mitsuhashi, H. Shima, T. Kawamura, K. Kikuchi, M. Oikawa, A. Ichihara, H. Oikawa, Bioorg. Med. Chem. Lett. 1999, 9, 2007 2012; g) K. Kikuchi, H. Shima, S. Mitsuhashi, M. Suzuki, H. Oikawa, Drugs Future 2000, 25, 501-507.

[4] K. T. Mead, B. N. Brewer, Curr. Org. Chem. 2003, 7, 227-256.

[5] a) E. M. Seward, E. Carlson, T. Harrison, K. R. Haworth, R. Herbert, F. J. Kelleher, M. M. Kurtz, J. Moselev, S. N. Owen, A. P. Owens, S. J. Sadowski, C. J. Swain, B. J. Williams, Bioorg. Med. Chem. Lett. 2002, 12, 2515-2518; b) J. D. Moseley, C. J. Swain, WO 97/30056, 1997.
[6] P. T. Meinke, H. Mrozik, US 5162363, 1992.

[7] A. Tursun, B. Aboab, I. Canet, M.-E. Sinibaldi, Tetrahedron Lett. 2005, 46, 2291-2294.

[8] A. Tursun, B. Aboab, A.-S. Martin, M.-E. Sinibaldi, I. Canet, Synlett 2005, 15, 2397-2399.

[9] a) P. M. Sher, R. D. Kronenthal, J. Labelled Compd. Radiopharm. 1997, 39, 21-28; b) M. Hashimoto, Y. Hatanaka, J. Yang, J. Dhesi, G. D. Holman, Carbohydr. Res. 2001, 331, 119127.

[10] A.-H. Li, S. Moro, N. Forsyth, N. Melman, X.-D. Ji, K.-A. Jacobson, J. Med. Chem. 1999, 42, 706-721.

[11] a) A. K. M. Anisuzzaman, L. N. Owen, J. Chem. Soc., C 1967, $11,1021-1026$; b) P. C. Braga, US 4910220, 1988

[12] The physical data for $(2 R, 6 S, 8 R)-1 \mathrm{a}$ and $(2 R, 6 R, 8 S)-1 \mathbf{b}$ were in good agreement with those previously reported by $\mathrm{M}$. Lemaire, G. Jeminet, J.-G. Gourcy, G. Dauphin, Tetrahedron: Asymmetry 1993, 4, 2101-2108.

[13] R. J. Mears, H. E. Sailes, J. P. Watts, A. Whiting, J. Chem. Soc, Perkin Trans. 1 2000, 3250-3263.

Received: May 23, 2006 Published Online: September 8, 2006 